\title{
Organic onion biofortification using microalgae and humic acid
}

\author{
Biofortificação de cebolas orgânicas por microalgas e ácido húmico \\ Biofortificación orgánica de cebolla por microalgas y ácido húmico
}

Received: 10/04/2021 | Reviewed: 10/11/2021 | Accept: 10/12/2021| Published: 10/14/2021

Luiz Gabriel Gemin

ORCID: https://orcid.org/0000-0002-9940-8334 Federal University of Paraná, Brazil E-mail: gemin1988@hotmail.com

Gabriel Bocchetti de Lara

ORCID: https://orcid.org/0000-0002-9090-6812 Federal University of Paraná, Brazil E-mail: gabrielbdelara@gmail.com

Átila Francisco Mógor

ORCID: https://orcid.org/0000-0003-4199-9079 Federal University of Paraná, Brazil E-mail: afmogor@gmail.com

Gilda Mógor

ORCID: https://orcid.org/0000-0002-4480-4487 Federal University of Paraná, Brazil E-mail: gildamogor@gmail.com

Christiane de Queiroz

ORCID: https://orcid.org/0000-0002-6334-7891 Federal University of Paraná, Brazil E-mail: christiane.queiroz@gmail.com

\begin{abstract}
Biofortification can be understood as a strategy to raise nutrients levels in vegetables edible structures, which can positively interfere in human diet. Biofertilizers are an interesting option in alternative production systems, as they can increase food nutritional quality and contribute to plant development, while aiding environment sustainability as natural products. The use of microalgae and humic acid as biofertilizers points to improvements in nutrients and biomolecules content in plants, however, their combined application is still unexplored. In that scenario, it was carried a study with onions about the influence of applications via root immersion in microalgae Scenedesmus subspicatus (Sc) and humic acid (HA) solutions, analyzing possible alterations of macro and micronutrients, total sugars, reducing sugar, free total amino acids, , total soluble solids, soluble proteins and antioxidant capacity in the bulbs. Treatments consisted of one minute seedlings roots immersion from two onion cultivars in solutions containing microalgae and humic acid, and then transplanted to organic system field. There were used three concentrations: control, $0.3 \mathrm{~g} \mathrm{~L}^{-1} \mathrm{Sc}$ $+0.3 \mathrm{~g} \mathrm{~L}^{-1} \mathrm{HA}(3 \mathrm{SH})$ and $0.6 \mathrm{~g} \mathrm{~L}^{-1} \mathrm{Sc}+0.6 \mathrm{~g} \mathrm{~L}^{-1} \mathrm{HA}(6 \mathrm{SH})$. Results show that the treatments with microalgae with humic acid association were able to increase the content of $\mathrm{N}$, carbohydrates and soluble proteins, also elevating antioxidant activity in onion bulbs.
\end{abstract}

Keywords: Allium cepa L.; Humic substances; Organic agriculture; Scenedesmus subspicatus.

\section{Resumo}

A biofortificação pode ser entendida como uma estratégia para elevar os níveis de nutrientes nas estruturas comestíveis dos vegetais, o que pode interferir positivamente na dieta humana. Os biofertilizantes são uma opção interessante em sistemas alternativos de produção, pois podem aumentar a qualidade nutricional dos alimentos e contribuir para o desenvolvimento das plantas, ao mesmo tempo que auxiliam na sustentabilidade do meio ambiente como produtos naturais. $\mathrm{O}$ uso de microalgas e ácido húmico como biofertilizante aponta para melhorias no teor de nutrientes e biomoléculas nas plantas, porém sua aplicação conjunta ainda é inexplorada. Nesse cenário, foi realizado um estudo com cebolas sobre a influência das aplicações via imersão radicular em soluções de microalgas Scenedesmus subspicatus (Sc) e ácido húmico (HA), analisando possíveis alterações de macro e micronutrientes, açúcares totais, açúcares redutores, sólidos solúveis totais, aminoácidos livres totais, proteínas solúveis e capacidade antioxidante nos bulbos. Os tratamentos consistiram na imersão das raízes das mudas de duas cultivares de cebola em soluções contendo microalgas e ácido húmico por um minuto, e posteriormente transplantadas para o campo do sistema orgânico. Foram utilizadas três concentrações: controle, $0,3 \mathrm{~g} \mathrm{~L}^{-1} \mathrm{Sc}+0,3 \mathrm{~g} \mathrm{~L}^{-1} \mathrm{HA}(3 \mathrm{SH})$ e $0,6 \mathrm{~g} \mathrm{~L}^{-1} \mathrm{Sc}+0,6$ $\mathrm{g} \mathrm{L}^{-1} \mathrm{HA}(6 \mathrm{SH})$. Os resultados mostram que os tratamentos com microalgas com associação de ácidos húmicos foram capazes de aumentar o teor de $\mathrm{N}$, carboidratos e proteínas solúveis, elevando também a atividade antioxidante em bulbos de cebola.

Palavras-chave: Allium cepa L.; Substâncias húmicas; Agricultura orgânica; Scenedesmus subspicatus. 


\section{Resumen}

La biofortificación puede entenderse como una estrategia para aumentar los niveles de nutrientes en las estructuras comestibles de los vegetales, lo que puede interferir positivamente en la dieta humana. Los biofertilizantes son una opción interesante en los sistemas de producción alternativos, ya que pueden incrementar la calidad nutricional de los alimentos y contribuir al desarrollo de las plantas, al mismo tiempo que ayudan a mantener el medio ambiente como productos naturales. El uso de microalgas y ácido húmico como biofertilizantes apunta a mejoras en el contenido de nutrientes y biomoléculas en las plantas, pero su aplicación conjunta aún no se ha explorado. En este escenario, se realizó un estudio con cebollas sobre la influencia de aplicaciones vía inmersión radicular en soluciones de microalgas Scenedesmus subspicatus (Sc) y ácido húmico (HA), analizando posibles cambios en macro y micronutrientes, azúcares totales, azúcares reductores, sólidos solubles totales, aminoácidos libres totales, proteínas solubles y capacidad antioxidante en bulbos. Los tratamientos consistieron en sumergir las raíces de plántulas de dos cultivares de cebolla en soluciones que contenían microalgas y ácido húmico durante un minuto, y luego trasplantarlas al campo del sistema orgánico. Se utilizaron tres concentraciones: control, 0,3 $\mathrm{g} \mathrm{L}^{-1} \mathrm{Sc}+0,3 \mathrm{~g} \mathrm{~L}^{-1} \mathrm{HA}(3 \mathrm{SH})$ y $0,6 \mathrm{~g} \mathrm{~L} \mathrm{Sc}^{-1}$ $0,6 \mathrm{~g} \mathrm{~L}^{-1} \mathrm{HA}(6 \mathrm{SH})$. Los resultados muestran que los tratamientos con microalgas con asociación de ácidos húmicos fueron capaces de incrementar el contenido de $\mathrm{N}$, carbohidratos y proteínas solubles, aumentando también la actividad antioxidante en bulbos de cebolla.

Palabras clave: Allium cepa L.; Substancias húmicas; Agricultura orgânica; Scenedesmus subspicatus.

\section{Introduction}

Originated from the Asian continent, onion (Allium cepa L.) is a horticultural specie with great importance. The world production of this bulb grew by 22\% between 2010 and 2017, led by China, and Brazil ranking among the first ten (FAO, 2020). Given onion importance in Brazil, its production is only surpassed by potatoes and tomatoes (Kurtz, et al., 2013).

The organic vegetable production in recent years has grown globally (Madail, et al., 2015), driven by a greater consumer demand for foods with higher nutritional value and free from chemical contamination, when compared to the conventional system (Barański, et al., 2017). In addition, Ren, et al., (2017) observed that bulbs obtained from organic systems have a higher concentration of flavonoids and antioxidant activity.

In that matter, onion bulbs have relevant nutritional properties, being rich in minerals, carbohydrates, proteins, ascorbic acid (Vethamoni \& Gomathi, 2018), and polyphenols that can significantly contribute to the human diet (Hossain, et al., 2018). Additionally, bulbs also contain molecules that confer a high antioxidant capacity, such as quercetin, kaempferol, miricetin and catechin flavonoids (Karadeniz, et al., 2005).

O'Hare (2015) defines plant Biofortification as a practice that promotes nutrients levels during growth and development of vegetable edible parts. In this sense, technologies that can be used at organic production system that promote fresh food biofortification become relevant not only for human health, but also the environment.

In that scenario, as microalgae use in agriculture is a growing subject, it's noted that biofertilizers from its source are still little explored (Ronga, et al., 2019). Meanwhile, researches already show the potential of microalgae Scenedesmus sp. application as a plant growth promoter by increasing proteins and the activity of primary metabolism enzymes (Puglisi, et al., 2020).

In similarity, humic acid is another promising biofertilizer source due to its concrete results in agriculture (Canellas, et al., 2015). Studies with onions and tomatoes subjected to the application of humic substances, show productivity gains as well as greater accumulations of amino acids, sugars and vitamin C (Bettoni, et al., 2016; Hussein, et al., 2015)

Furthermore, humic acids and algae extracts applications in plants can be considered agronomic biofortification techniques, as they have potential to increase nutrient content and positively alter the concentration of total sugars, amino acids, proteins and phenolic compounds (Billard, et al., 2014; Conselvan, et al., 2017; Dineshkumar, et al., 2018). Nevertheless, the association of microalgae with humic substances is still untapped. In this sense, this works objective was to explore microalgae Scenedesmus subspicatus (Sc) and humic acid (HA) applications as biofortification substances in organic onion. 


\section{Methodology}

The biomass from Scenedesmus subspicatus (Sc) Chodat microalgae (synonym: Desmodesmus subspicatus), deposited in the "Elizabeth Aidar" Microalgae Collection at the Fluminense Federal University, Niterói, Rio de Janeiro Brazil, was obtained through an autotrophic cultivation system using WC culture medium in constant temperature $\left(20-22^{\circ} \mathrm{C}\right)$ and light (5500 lux), at the Plant Science and Crop Protection Department of Federal University of Paraná (UFPR), Curitiba, Paraná - Brazil. After 25 days, the biomass was centrifuged and lyophilized, to be ready for use. The Humic acid (HA) used came from Leonardite minerals which contains $33 \%$ organic carbon (Powhumus ${ }^{\circledR}$ Humintech GmbH - Germany).

The onion cultivars chosen were BR-29 ('B') and Perfecta F1 ('P') from Topseed ${ }^{\circledR}$. Seedlings were produced in a tunnel-type nursery covered with polyethylene in beds. After 45 days after sowing (DAS), seedlings were collected for planting in a bed measuring $1.20 \times 24 \mathrm{~m}$, and distributed in plots of $1.20 \times 1.0 \mathrm{~m}$, using $10 \mathrm{~cm}$ spacing between plants and 30 $\mathrm{cm}$ between lines, resulting in a population of 230 thousand plants per hectare.

Treatments consisted of aqueous solutions containing microalgae (Sc) and humic acid (HA) were applied via immersion in onion seedling roots for one minute. The solutions concentrations were: $0.3 \mathrm{~g} \mathrm{~L}^{-1} \mathrm{Sc}+0.3 \mathrm{~g} \mathrm{~L}-1 \mathrm{HA}(3 \mathrm{SH}), 0.6 \mathrm{~g}$ $\mathrm{L}^{-1} \mathrm{Sc}+0.6 \mathrm{~g} \mathrm{~L}^{-1} \mathrm{HA}(6 \mathrm{SH})$ and distilled water (control). At 150 days after transplanting (DAT), about $80 \%$ of the plants had their aerial part dropped close to the ground (top collapse), to help bulb harvest. Thus, after harvesting, bulbs from each repetition and cultivar were sampled for the analysis of nutrient, biochemical and antioxidant content.

Therefore, this experiment was conducted in a completely randomized design in a factorial scheme, with factor A composed of cultivars ('B' and 'P') and factor B of treatments (control, 3SH and 6SH) with four repetitions each. This study was performed at the Organic Vegetable Production Research Area, under organic system since 2006, at the Federal University of Paraná, metropolitan region of Curitiba (latitude $25^{\circ} 25^{\prime}$ 'south, longitude $49^{\circ} 06^{\prime}$ west and $920 \mathrm{~m}$ altitude), in June 2019. The region climate, according to Köppen-Geiger classification is $\mathrm{Cfb}$, which characterizes this region as Temperate. The soil

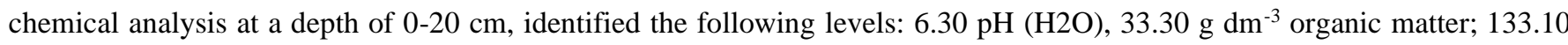
$\mathrm{mg} \mathrm{dm}{ }^{-3} \mathrm{P} ; 1.44 \mathrm{cmol} \mathrm{cdm}^{-3} \mathrm{~K} ; 9.30 \mathrm{cmol} \mathrm{cdm}^{-3} \mathrm{Ca} ; 4.30 \mathrm{cmol} \mathrm{cdm}^{-3} \mathrm{Mg} ; 0 \mathrm{cmol} \mathrm{cdm} \mathrm{cl}^{-3} \mathrm{Al} ; 3.7 \mathrm{cmol} \mathrm{cdm}^{-3} \mathrm{Al}+\mathrm{H} ; 18.34 \mathrm{cmol}^{2}$ $\mathrm{cdm}^{-3} \mathrm{CTC}$ and $80 \%$ base saturation.

Further, for the chemical analysis, 2 bulbs were collected per repetition to quantify macro and micronutrient contents $(\mathrm{N}, \mathrm{K}, \mathrm{P}, \mathrm{Ca}, \mathrm{Mg}, \mathrm{Cu}, \mathrm{Mn}, \mathrm{Fe}, \mathrm{Zn}$ and B). After that, in order to obtain the dry mass from each sample, a greenhouse with temperature $\left(60^{\circ} \mathrm{C} \pm 5^{\circ} \mathrm{C}\right)$ and forced ventilation were used until the samples presented constant weight. Samples with $0.3 \mathrm{~g}$ of dry bulb mass were extracted by acid digestion as described by Martins \& Reissmann, 2007. After this procedure, nutrient contents were determined using the induction plasma optical emission spectroscopy methods with a Perkin Elmer Optima 4300 (Perkin Elmer, USA) in triplicate samples. The quantification of nitrogen (n-total) was performed by combustion in a CHONS analyzer (Vario EL III model).

In order to quantify total sugars, reducing sugar, total free amino acids and soluble proteins, for biochemical analysis, two bulbs were collected per repetition from each cultivar. To quantify the total soluble solids (Brix ${ }^{\circ}$ ) a refractometer was used in each treatment. For the quantification of total and reducing sugars, bulbs samples were prepared in microtubes plus distilled water, and subsequently taken to the vortex. After this process, the microtubes were placed in a centrifuge for 10 minutes $(10,000 \mathrm{rpm})$. For total sugars extraction, the homogenized sample was added in test tubes with $1 \mathrm{ml}$ of $\mathrm{HCl}$ for acid hydrolysis in water bath for 10 minutes. Then $1 \mathrm{ml}$ of $\mathrm{NaOH}$ solution was added, leaving it to rest for 5 minutes. After this procedure, the DNS reagent was added to the total and reducing sugar samples, then samples temperature were cooled by ice bath, allowing spectrophotometer readings $(540 \mathrm{~nm})$. The standard curve for reducing and total sugars was established with glucose at $1 \mathrm{mg} / \mathrm{mL}(5.5 \mathrm{mM})$ with values between 50 to $800 \mu \mathrm{g} / \mathrm{mL}$ (Maldonade et al., 2013).

Following Winters, et al. (2002) methodology the extraction of total free amino acids were carried, and the 
colorimetric reaction was according to Magné \& Larher (1992), using glutamine for the standard curve. Test tubes with vegetable samples and distilled water were used to extract amino acids. Then they were taken to a water bath at $100^{\circ} \mathrm{C}$ for 15 minutes, and left to cool, allowing the sample to decant after 20 minutes in an ice bath. The supernatant was removed from the samples into new microtubes and centrifuged at $3000 \mathrm{rpm}$ for 10 minutes. For the colorimetric reaction it was added $1 \mathrm{ml}$ of the sample, $0.5 \mathrm{ml}$ of citrate buffer, $1 \mathrm{ml}$ of ninhydrin and used vortex for 2 seconds. Subsequently, a water bath was applied for 15 minutes at $100^{\circ} \mathrm{C}$, allowing it to cool, before adding $60 \%$ alcohol. The readings were carried out on a spectrophotometer at $570 \mathrm{~nm}$.

The methodology chosen for soluble proteins extraction was described by Bradford (1976), using BSA reagent for the standard curve construction. It was added $0.5 \mathrm{~g}$ of plant sample plus $1.5 \mathrm{ml}$ of phosphate buffer as described by Du, et al. (2010). After this procedure, samples were centrifuged for 15 minutes at $10,000 \mathrm{rpm}$. Then, $70 \mu \mathrm{L}$ of the supernatant was added to the homogenized sample, plus $2 \mathrm{ml}$ of the Bradford reagent, letting it rest for 15 minutes, thus making it possible to the sample readings on a spectrophotometer $(595 \mathrm{~nm})$.

The antioxidant action was estimated using standard 1,1-diphenyl-2-picryl-hydrazil (DPPH) using Brand-Williams et al. (1995) methodology. Samples of $0.5 \mathrm{~g}$ from onion bulbs were used, subsequently diluted into distilled water and centrifuged for five minutes. After this procedure, $0.1 \mathrm{ml}$ of the supernatant was removed from the samples and transferred to test tubes that contained $4.9 \mathrm{ml}$ of the DPPH reagent. Then the samples were left to rest for 40 minutes for measurement in a spectrophotometer $(517 \mathrm{~nm})$.

Collected data were first verified for its variance homogeneity by Bartlett's test. When significant, the results were subjected to analysis of variance (ANOVA), with averages compared by Scott-Knott's test $(p<0.05 ; p<0.01$ ), using ASSISTAT 7.7 beta version statistical analysis software (Silva \& Azevedo, 2016).

\section{Results}

In 'P' bulbs (Figure 1), treatments containing microalgae associated with humic acid did not have influence in the increase of nutrient content. However, $3 \mathrm{SH}$ and $6 \mathrm{SH}$ treatments via immersion increased $\mathrm{N}$ levels by 17 and 29\% in 'B' bulbs, respectively, when compared to the control, showing no statistic difference for other nutrients. In comparison between cultivars, 'P' bulbs presented, on average, higher K (18.9\%), Ca (33\%), Mg (19\%), Mn (66.2\%), Fe (296\%) and B (33.8\%). In contrast, 'B' bulbs showed a higher concentration of $\mathrm{P}(15.3 \%), \mathrm{Cu}(23 \%)$ and $\mathrm{Zn}(20.4 \%)$. The concentration of the mineral nitrogen was on average statistically equal for both cultivars. 
Figure 1. Nutrients content in organically grown onion bulbs (dry mass), whose seedlings were immersed for one minute in solutions of the biomass of microalgae Scenedesmus subspicatus $(\mathrm{Sc})$ in association with humic acid (HA).
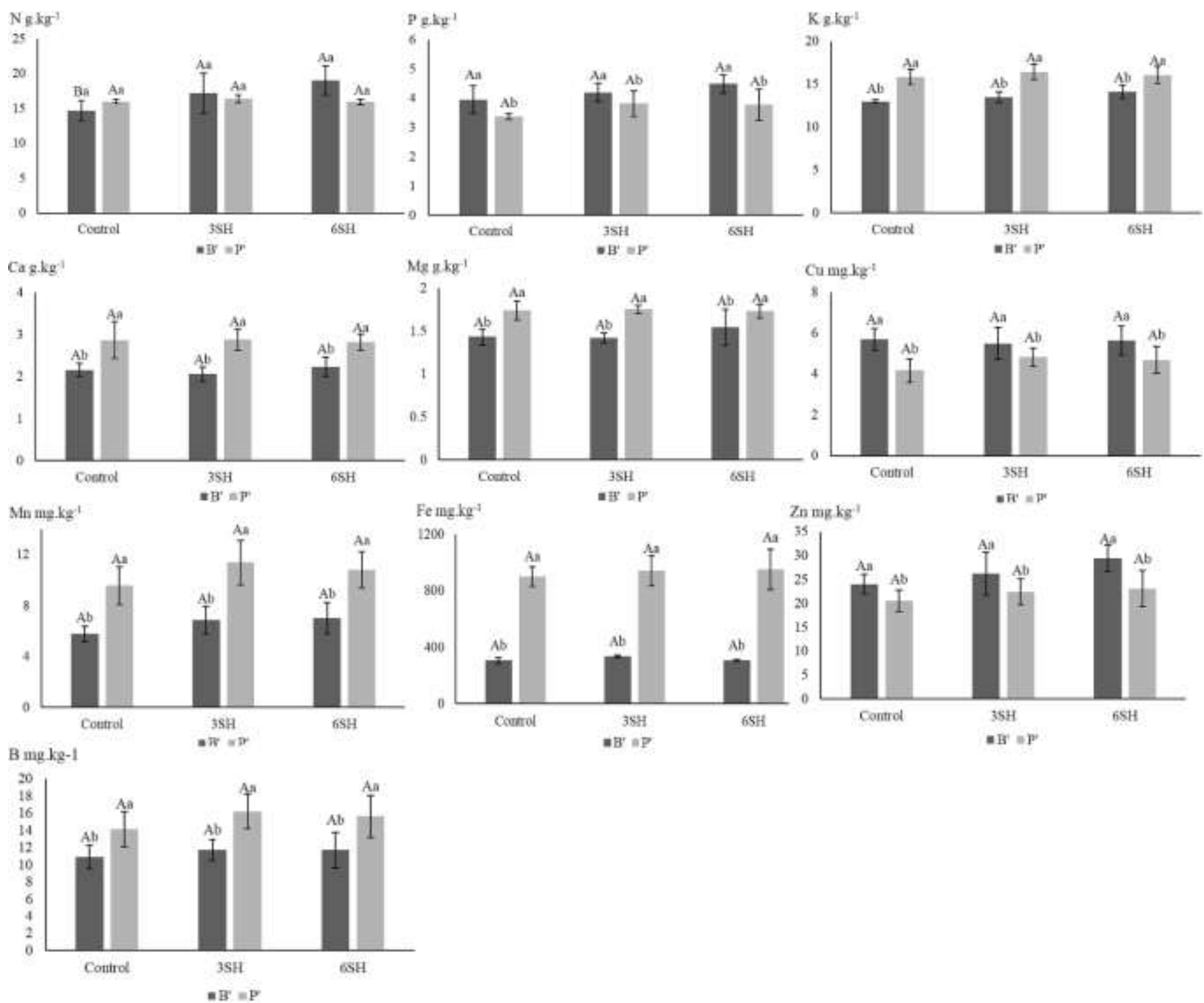

Onion cultivars ('B' = BR-29; 'P' = Perfecta F1). Immersion treatments: control, $3 \mathrm{SH}=\left(0.30 \mathrm{~g} \mathrm{~L}^{-1} \mathrm{Sc}+0.30 \mathrm{~g} \mathrm{~L}{ }^{-1} \mathrm{HA}\right), 6 \mathrm{SH}=\left(0.60 \mathrm{~g} \mathrm{~L}{ }^{-1} \mathrm{Sc}\right.$ $+0.60 \mathrm{~g} \mathrm{~L}^{-1} \mathrm{HA}$ ). Capital letters $=$ treatments. Lower case letters $=$ cultivars. Bars represent standard deviation. Means followed by the same letter do not differ statistically in Skott-Knott test $(\mathrm{p} \leq 0.05)$.

Source: Authors.

The treatments contributed to the increase in total and reducing sugars concentration in bulbs when compared to the control. In 'B' bulbs, the concentration of total sugars (Figure 2AB) showed an increase of $48 \%$ when compared to 'P' bulbs. Meanwhile, the content of reducing sugar in 'P' bulbs was significantly higher (62\%) when compared to 'B' bulbs.

The content of total free amino acids (Figure 2C) in 'B' bulbs was higher (82\%) when compared to 'P', however, without effect between treatments. The content of soluble proteins (Figure 2D), showed interaction factor between cultivars and treatments. Applications of $6 \mathrm{SH}$ promoted a significant increase in 'B' bulbs (18\%). While in 'P', the application of $3 \mathrm{SH}$ significantly increased soluble proteins (37\%) when compared to the control. 
Figure 2. Total sugars content (A), reducing sugars (B), total free amino acids (C) and soluble proteins (D) in organically grown onion bulbs whose seedlings were immersed for one minute in solutions of the biomass of microalgae Scenedesmus subspicatus $(\mathrm{Sc})$ in association with humic acid (HA).
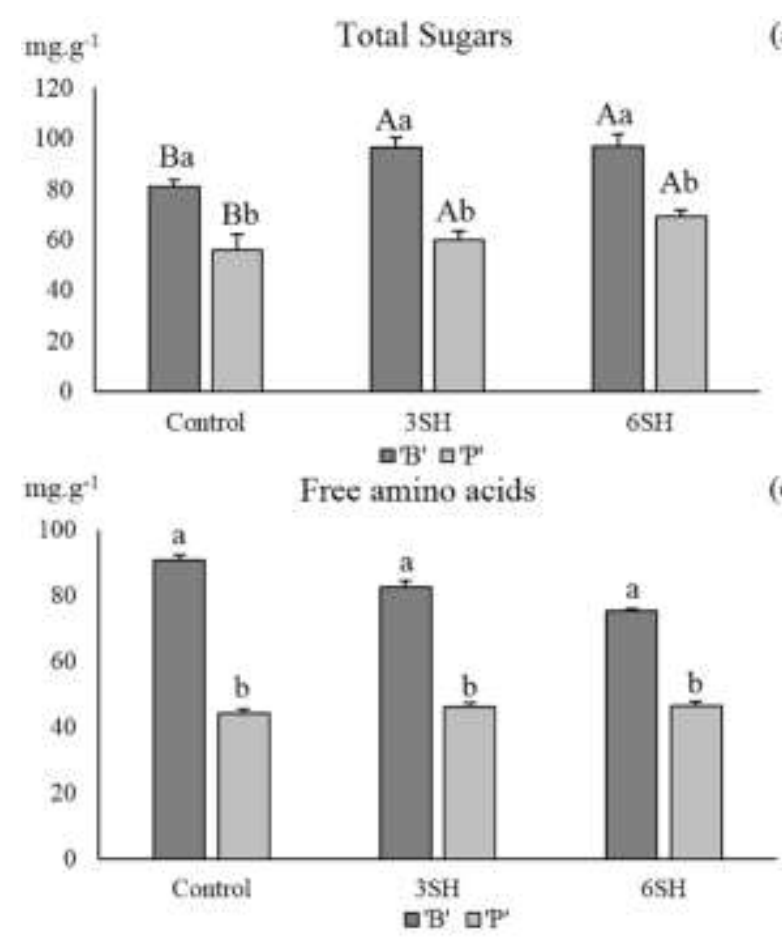

(a)

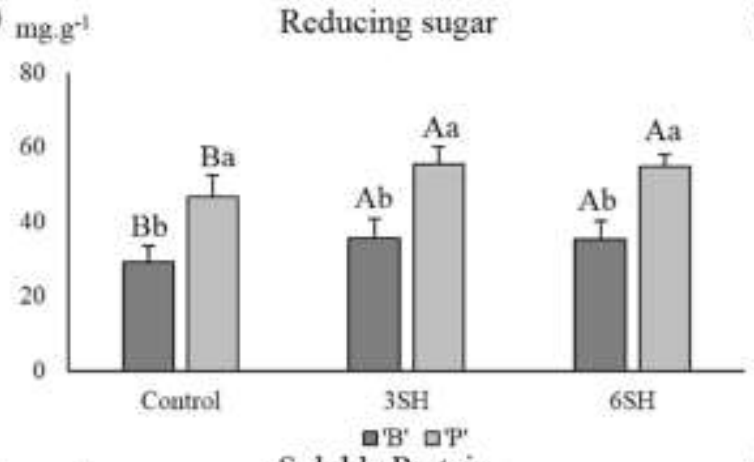

(c)

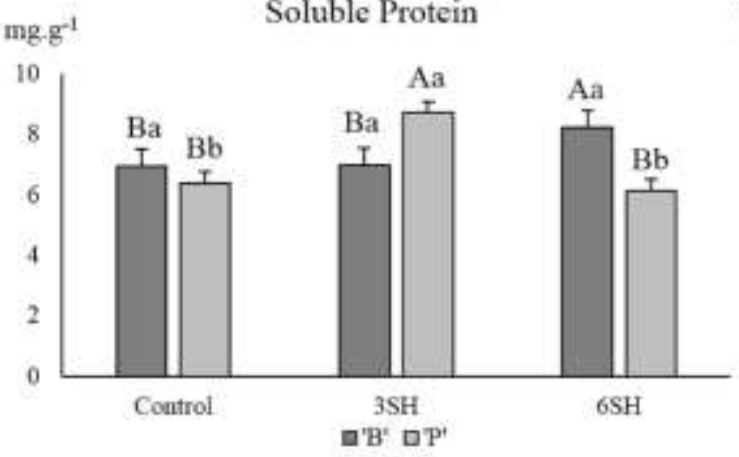

(b)

(d)

Onion cultivars: 'B" $=\mathrm{BR}-29$; 'P' $=$ Perfecta F1. Immersion treatments: control, $3 \mathrm{SH}=\left(0.30 \mathrm{~g} \mathrm{~L}^{-1} \mathrm{Sc}+0.30 \mathrm{~g} \mathrm{~L}{ }^{-1} \mathrm{HA}\right), 6 \mathrm{SH}=\left(0.60 \mathrm{~g} \mathrm{~L}{ }^{-1} \mathrm{Sc}\right.$ $\left.+0.60 \mathrm{~g} \mathrm{~L}^{-1} \mathrm{HA}\right)$. Columns with the same letter do not differ statistically by Scott-Knott's test $(\mathrm{p}<0.05)(\mathrm{n}=4)$. Capital letters $=$ treatments. Lower case letters $=$ cultivars. Bars represent standard deviation.

Source: Authors.

Additionally, there was a significant difference in antioxidant activity between cultivars and treatments (Figure 3). The 'P' bulbs showed greater capacity (37\%) to scavenge free radicals (DPPH) when compared to the 'B' bulbs. There was no statistical difference between treatments in the cultivar 'P'. However, in cultivar 'B' higher antioxidant capacity was observed in the control and $6 \mathrm{SH}$ treatments when compared to the $3 \mathrm{SH}$ treatment. In addition, the $6 \mathrm{SH}$ treatment in 'B', on average, showed antioxidant capacity statistically equal to that found in ' $\mathrm{P}$ ' bulbs, which also showed greater antioxidant capacity. 
Figure 3. Antioxidant capacity in organically grown onion bulbs, whose seedlings were immersed for one minute in solutions of the biomass of microalgae Scenedesmus subspicatus (Sc) in association with humic acid (HA).

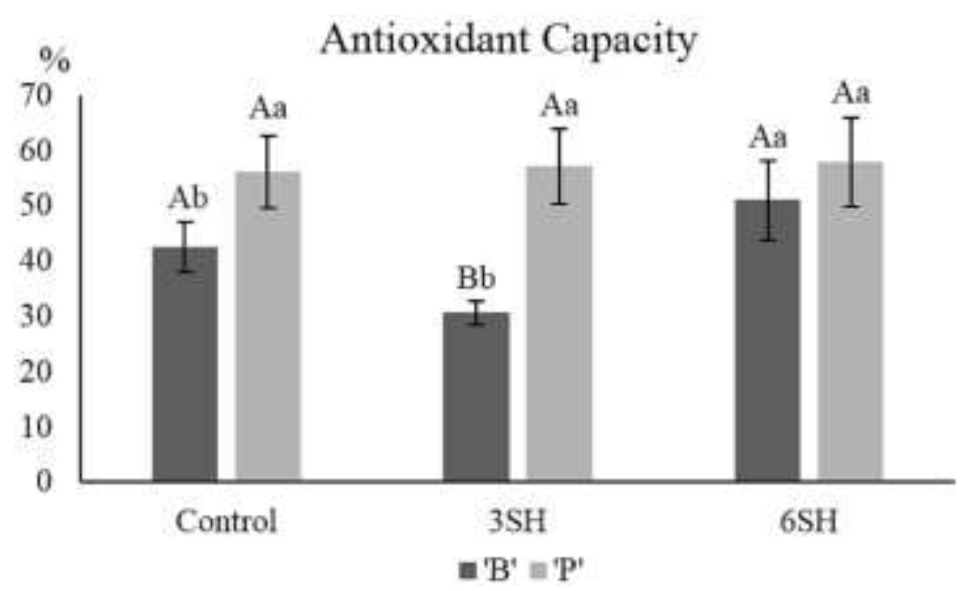

Onion cultivars: 'B' = BR-29; 'P' $=$ Perfecta F1. Immersion treatments: control, $3 \mathrm{SH}=\left(0.30 \mathrm{~g} \mathrm{~L}^{-1} \mathrm{Sc}+0.30 \mathrm{~g} \mathrm{~L} \mathrm{~L}^{-1} \mathrm{HA}\right), 6 \mathrm{SH}=(0.60 \mathrm{~g} \mathrm{~L}-1$ $\left.\mathrm{Sc}+0.60 \mathrm{~g} \mathrm{~L}^{-1} \mathrm{HA}\right)$. Columns with the same letter do not differ statistically by Scott-Knott's test $(\mathrm{p}<0.01)(\mathrm{n}=4)$. Capital letters $=$ treatments. Lower case letters = cultivars. Bars represent standard deviation.

Source: Authors.

\section{Discussion}

Studies point to the potential benefits to human health in ingesting fresh onions, as this bulb is considerate to have high nutritional value, which may vary in nutrient composition between different cultivars (Kumar, et al., 2010). In particular, nitrogen is an essential nutrient for human and plant metabolism in stimulating protein synthesis (Al-Fraihat, 2009; Vianna, et al., 2010). In this sense, Bettoni, et al. (2016) observed that about 2.8\%, on average, of different onion cultivars mass, is composed of nitrogen. An even superior result to 'B' (1.69\% of N) and 'P' (1.60\% of N) bulb cultivars used in this work.

An increase in the $\mathrm{N}$ content in the 'B' bulbs was observed in the treatments with $3 \mathrm{SH}$ and $6 \mathrm{SH}$ provided, which may be related to humic acid effect, which when applied to plants promotes involved enzymes activation in the reduction and assimilation of inorganic nitrogen (Nitrate reductase, Nitrite reductase, GS and GOGAT) (Vaccaro, et al., 2015). In addition, microalgae biomass may contain phytohormones, vitamins and enzymes that favor greater assimilation of nutrients in drains of higher priority (Shaaban, et al., 2001).

Moreover, Dias (2012) points out that plants of Liliaceas family, such as onion and garlic, are rich in potassium, calcium and manganese, making possible to supply $10 \%$ of human daily needs with the consumption of these vegetables. In 1 $\mathrm{g}$ of fresh onion bulb mass, the concentration of potassium and calcium is $1.46 \mathrm{mg}$ and $0.23 \mathrm{mg}$ of calcium respectively (USDA, 2019), which are higher than those observed in the 'B' and 'P' bulbs (Figure 1), as the highest content of these nutrients were quantified in hybrid cultivar bulbs. Phosphorus was the third most accumulated nutrient in bulbs, with magnesium being the nutrient with the lowest content in bulbs, a result similar to that found by Bettoni, et al. (2016).

In addition to iron supplementation in diets to combat anemia, the consumption of foods rich in this micronutrient can help decrease the population risk of iron deficiency (Leão, et al., 2018). A research shown average values of Fe content in onion bulbs of $744 \mu \mathrm{g} \mathrm{g}^{-1}$ (Vidigal, et al., 2010). Result that may vary from each cultivar, as observed in bulbs of 'P' (930 $\mu \mathrm{g} \mathrm{g}^{-}$ ${ }^{1}$ ), displaying greater Fe accumulation capacity when compared to 'B' (314 $\left.\mu \mathrm{g} \mathrm{g}^{-1}\right)$, showing that the hybrid cultivar has greater potential in preventing nutritional disorders like anemia.

Additionally, within the same plant species there is variation in chemical elements concentration, as observed in the onion genotypes studied when comparing the micronutrients Mn, Zn, B and Cu (White \& Broadley, 2005).

In dry matter fraction of onion bulbs, approximately $80 \%$ is composed of non-structural carbohydrates, which are 
reducing sugars such as glucose and fructose, as well as sucrose non-reducing sugar and fruits-oligosaccharides (Zhang, et al., 2016). On this wise, soluble solids are related to the sweet taste of onion, being composed of fructans, fructose, glucose and sucrose (Mallor, et al., 2011).

Furthermore, studies with humic acid application in onion plants show an increase in the concentration of reducing sugars and starch in the bulbs (Bettoni, et al., 2016), as well as the microalgae Nannochloropsi ssp. and Scenedesmus subspicatus, which when applied to tomato and onion plants respectively, promoted an increase in carbohydrates (Coppens, et al., 2016). It was verified that in two onion cultivars bulbs the ${ }^{\circ}$ Brix values were the same between treatments $(p>0.05)$. However, cultivar ' $\mathrm{P}$ ' showed higher values of ${ }^{\circ} \mathrm{Brix}$ (44\%) when compared to ' $\mathrm{B}$ '. The average values of ${ }^{\circ} \mathrm{Brix}$ in the 'B' and 'P' bulbs are respectively: control $=5.17$ and $8.0 ; 3 \mathrm{SH}=6.25$ and $8.05 ; 6 \mathrm{SH}=5.57$ and 8.45. The contribution of humic acid and microalgae use as a tool in increasing the carbohydrate content in the bulbs is relevant, since this technology can help farmers to obtain a sweeter onion.

It is known that biofertilizers are capable of promoting the increase of soluble proteins in plants, improving $\mathrm{N}$ assimilation and stimulating amino acids metabolism (Nardi, et al., 2016). Although, it was not clear the response to the treatments containing microalgae associated with humic acid, as it promoted 'B' and ' $\mathrm{P}$ ' greater accumulations of soluble proteins treated with $6 \mathrm{SH}$ and $3 \mathrm{SH}$ respectively, but it had different results in the concentration of total free amino acids and $\mathrm{N}$ content in 'P' bulbs when treated with the biofertilizer.

Among vegetables, onion has a high antioxidant capacity because it contains anthocyanins and flavonoids in its composition, with quercetin being the flavonoid with the highest concentration in its bulbs (Suleria, et al., 2015). In such matter, it was observed a greater antioxidant activity and higher flavonoids concentrations in onions conducted at organic system when compared to conventional, a significant result for alternative production systems and for the consumer (Ren, et al., 2017).

Researches with humic acid application in plants demonstrate the potential to activate secondary metabolism. Schiavon, et al. (2010) shows that humic substances applications increased the expression of phenylalanine amonialiasis enzyme, responsible for the first step in phenolic compounds biosynthesis. In addition to having a growth-promoting effect on vegetables, microalgae act as elicitors in the plant's defensive system, increasing the concentration of peroxidases, polyphenol oxidase and phenylalanine amonialiase, enzymes that act as antioxidants in plants (Renuka, et al., 2018 ). It was observed that the antioxidant capacity varies with the onion genotype, this result was also observed by Lu, et al, (2011). In addition, the biofertilizer application in $6 \mathrm{SH}$ concentration stimulates 'B' bulbs to achieve an antioxidant capacity statistically equal to that found in 'P' bulbs, a genotype that showed greater antioxidant capacity.

\section{Conclusion}

Biofertilizer use containing Scenedesmus subspicatus microalgae in association with humic acid promoted an increase in the $\mathrm{N}$ content in the open pollinated cultivar. In addition, the biofertilizer provided greater accumulation of carbohydrates and soluble proteins in both cultivars bulbs, and the treatment containing $0.6 \mathrm{~g} \mathrm{~L}^{-1} \mathrm{Sc}+0.6 \mathrm{~g} \mathrm{~L}^{-1} \mathrm{HA}$ increased antioxidant capacity in the BR-29 cultivar.

\section{Acknowledgments}

The author thanks National Research Council of Brazil (CNPq) for his Doctoral scholarship (grant 142393/2016-9). 


\section{References}

Al-Fraihat, A. H. (2009). Effect of different nitrogen and sulphur fertilizer levels on growth, yield and quality of onion (Allium cepa L.). Jordan Journal of Agricultural Sciences, 5, 155-165.

Barański, M., Rempelos, L., Iversen, P. O., \& Leifert, C. (2017). Effects of organic food consumption on human health; the jury is still out! Food \& Nutrition Research, 61, 1-5. doi: 10.1080/16546628.2017.1287333

Bettoni, M. M., Mogor, Á. F., Pauletti, V.; Goicoechea, N.; Aranjuelo, I., \& Garmendia, I. (2016). Nutritional quality and yield of onion as affected by different application methods and doses of humic substances. Journal of Food Composition and Analysis, 51, 37-44. doi: 10.1016/j.jfca.2016.06.008

Billard, V., Etienne, P., Jannin, L., Garnica, M., Cruz, F., Garcia-Mina, J. M., \& Ourry, A. (2014). Two biostimulants derived from algae or humic acid induce similar responses in the mineral content and gene expression of winter oilseed rape (Brassica napus L.). Journal of plant growth regulation, 33, 305-316. doi: $10.1007 / \mathrm{s} 00344-013-9372-2$

Bradford, M. M. (1976). A rapid and sensitive method for the quantitation of microgram quantities of protein utilizing the principle of protein-dye binding. Analytical biochemistry, 72, 248-254. doi: 10.1016/0003-2697(76)90527-3

Brand-Williams, W., Cuvelier, M.E., \& Berset, C. (1995). Use of a free radical method to evaluate antioxidant activity. Lebensmittel-Wissenschaft \& Technologie, 28, 25-30. doi: 10.1016/S0023-6438(95)80008-5

Canellas, L. P., Olivares, F. L., Aguiar, N. O., Jones, D. L., Nebbioso, A., Mazzei, P., \& Piccolo, A. (2015). Humic and fulvic acids as biostimulants in horticulture. Scientia Horticulturae, 196, 15-27. doi: 10.1016/j.scienta.2015.09.013

Conselvan, G. B., Pizzeghello, D., Francioso, O., Di Foggia, M., Nardi, S.; \& Carletti, P. (2017). Biostimulant activity of humic substances extracted from leonardites. Plant and Soil, 420, 119-134. doi: doi.org/10.1007/s11104-017-3373-Z

Coppens, J., Grunert, O., Van Den Hende, S., Vanhoutte, I., Boon, N., Haesaert, G., \& De Gelder, L. (2016). The use of microalgae as a high-value organic slow-release fertilizer results in tomatoes with increased carotenoid and sugar levels. Journal of Applied Phycology, 28, 2367-2377. doi: 10.1007/s10811-0150775-2

Dias, J.S. (2012). Nutritional quality and health benefits of vegetables: a review. Food and Nutrition Sciences, 3, 1354-1374. doi: 10.4236/fns.2012.310179

Dineshkumar, R., Subramanian, J., Arumugam, A., Rasheeq, A. A., \& Sampathkumar, P. (2018). Exploring the Microalgae Biofertilizer Effect on Onion Cultivation by Field Experiment. Waste and Biomass Valorization 11, 77-87. doi: 10.1007/s12649-018-0466-8

Du, C. X., Fan, H. F., Guo, S. R., \& Tezuka, T. (2010). Applying spermidine for differential responses of antioxidant enzymes in cucumber subjected to shortterm salinity. Journal of the American Society for Horticultural Science, 135, 18-24. doi: 10.21273/JASHS.135.1.18

FAO (2020). Food and Agriculture Organization of the United Nations .Retrived:27 jun 2020. http://www.fao.org/faostat/en/\#data.

Hossain, M. B., Lebelle, J., Birsan, R., \& Rai, D. K. (2018). Enrichment and Assessment of the Contributions of the Major Polyphenols to the Total Antioxidant Activity of Onion Extracts: A Fractionation by Flash Chromatography Approach. Antioxidants 7: 175. doi: 10.3390/antiox7120175

Husein, M. E., El-Hassan, S. A., \& Shahein, M. M. (2015). Effect of humic, fulvic acid and calcium foliar application on growth and yield of tomato plants. International Journal of Biosciences, 7, 132-140.

Karadeniz, F., Burdurlu, H. S., Koca, N., \& Soyer, Y. (2005). Antioxidant activity of selected fruits and vegetable grown in Turkey. Turkish Journal of Agriculture and Forestry, 29, 297-303.

Kumar, K. S., Bhowmik, D., Chiranjib, B., \& Tiwari, P. (2010). Allium cepa: A traditional medicinal herb and its health benefits. Journal of Chemical and Pharmaceutical Research, 2, 283-291.

Kurtz, C., Ernani, P. R., Pauletti, V., Menezes Junior, F. O. G., \& Vieira Neto J. (2013). Produtividade e conservação de cebola afetadas pela adubação nitrogenada no sistema de plantio direto. Horticultura Brasileira, 31, 559-567. doi: 10.1590/S0102-05362013000400009

Leão, L. L., Antunes, B. A., Oliveira, C. A., Brito, M. F. S. F., \& Pinho, L. D. (2018). Alimentos fontes de ferro e vitamina c consumidos entre lactentes da atenção primária à saúde. Cogitare Enfermagem, 23, 1-9. doi: 10.5380/ce.v23i2.51908

Lu, X., Wang, J., Al-Qadiri, H. M., Ross, C. F., Powers, J. R., Tang, J., \& Rasco, B. A. (2011). Determination of total phenolic content and antioxidant capacity of onion (Allium cepa) and shallot (Allium oschaninii) using infrared spectroscopy. Food Chemistry, 129(2), 637-644. doi:10.1016/j.foodchem.2011.04.105

Madail, J. C. M., Belarmino, L. C., \& Bini, D. A. (2015). Evolução da produção e mercado de produtos orgânicos no Brasil e no Mundo. Rca-revista científica da ajes 2: 1-9.

Magné, C., \& Larher, F. (1992). High sugar contente interferes with colorimetric determination of amino acids and free proline. Analytical Biochemistry, 200, 115-118. doi: 10.1016/0003-2697(92)90285-F

Maldonade, I. R., De Carvalho, P. G. B., \& Ferreira. N. A. (2013). Protocolo para determinação de açúcares totais em hortaliças pelo método de DNS. Brasília, DF: Embrapa Hortaliças (Comunicado Técnico 85). 4 p.

Mallor, C., Balcells, M., Mallor, F., \& Sales, E. (2011). Genetic variation for bulb size, soluble solids content and pungency in the Spanish sweet onion variety Fuentes de Ebro. Response toselection for lowpungency. Plant Breeding, 130, 55-59. doi: 10.1111/j.1439-0523.2009. 01737.x

Martins, A. P., \& Reissmann, C. B. (2007). Material vegetal e as rotinas laboratoriais nos procedimentos químico-analíticos. Scientia Agraria Paranaensis, 8, $1-17$. 
Nardi, S., Pizzeghello, D., Schiavon, M., \& Ertani, A. (2016). Plant biostimulants: physiological responses induced by protein hydrolyzed-based products and humic substances in plant metabolism. Scientia Agricola, 73,18-23. doi: 10.1590/0103-9016-2015-0006

O'hare, T.J. (2015). Biofortification of vegetables for the developed world. Acta Horticulturae, 1106, 1-8. Doi: 10.17660/ActaHortic.2015.1106.1

Puglisi, I., La Bella, E., Rovetto, E. I., Lo Piero, A. R., \& Baglieri, A. (2020). Biostimulant effect and biochemical response in lettuce seedlings treated with a Scenedesmus quadricauda extract. Plants, 9, 123. doi: doi.org/10.3390/plants9010123

Ren, F., Reilly, K., Kerry, J. P., Gaffney, M., Hossain, M., \& Rai, D. K. (2017). Higher antioxidant activity, total flavonols, and specific quercetinglucosides in two different onion (Allium cepa L.) varieties grown under organic production: Results from a 6-year study. Journal of Agricultural and Food Chemistry, 65, 5122-5132. doi: 10.1021/acs.jafc.7b01352

Renuka, N., Guldhe, A., Prasanna, R., Singh, P., \& Bux, F. (2018). Microalgae as multi-functional options in modern agriculture: current trends, prospects and challenges. Biotechnology advances, 36, 1255-1273. doi: 10.1016/j.biotechadv.2018.04.004

Ronga, D., Biazzi, E., Parati, K., Carminati, D., Carminati, E., \& Tava, A. (2019). Microalgal Biostimulants and Biofertilisers in Crop Productions. Agronomy, 9, 192. doi: 10.3390/agronomy9040192

Schiavon, M., Pizzeghello, D., Muscolo, A., Vaccaro, S., Francioso, O., \& Nardi, S. (2010). High molecular size humic substances enhance phenylpropanoid metabolism in maize (Zea mays L.). Journal of chemical ecology, 36, 662-669. doi: 10.1007/s10886-010-9790-6

Shaaban, M.M. (2001). Green microalgae water extract as foliar feeding to wheat plants. Pakistan Journal of Biological Sciences, 4, $628-632$.

Silva, F. D. A. S., \& de Azevedo, C. A. V. (2016). The Assistat Software Version 7.7 and its use in the analysis of experimental data. African Journal of Agricultural Research, 11, 3733-3740. doi: 10.5897/AJAR2016.11522

Suleria, H. A. R., Butt, M. S., Anjum, F. M., Saeed, F., \& Khalid, N. (2015). Onion: Nature protection against physiological threats. Critical reviews in food science and nutrition, 55, 50-66. doi: doi.org/10.1080/10408398.2011.646364

USDA. (2019). - United States Department of Agriculture Agricultural Research Service. National Nutrient Database for Standard Reference Legacy Release. Retrived, 27 Jun. 2020. https://ndb.nal.usda.gov/ndb/foods/show/11282?fgcd=\&manu=\&format=\&count=\&max=25\&offset=\&sort=default\&or Der=asc\&qlookup $=$ Onions $\% 2 C+r a w \& d s=\& q \mathrm{t}=\& q p=\& q a=\& q n=\& q=\&$ ing $=$.

Vaccaro, S., Ertani, A., Nebbioso, A., Muscolo, A., Quaggiotti, S., Piccolo, A., \& Nardi, S. (2015). Humic substances stimulate maize nitrogen assimilation and aminoacid metabolism at physiological and molecular level. Chemical and Biological Technologies in Agriculture, 2, 5. doi: 10.1186/s40538-015-0033-5

Vethamoni, P. I., \& Gomathi, M. (2018). Effect of pre harvest treatments on quality and post-harvest losses of multiplier onion (Allium cepa L. var. aggregatum Don.). Journal of Pharmacognosy and Phytochemistry, 7, 2358-2362.

Vianna, D. T., Resende, G. F., Torres-Leal, F. L., \& Tirapegui, J. (2010). Protein synthesis regulation by leucine. Brazilian Journal of Pharmaceutical Sciences, 46, 29-36.

Vidigal, S. M., Moreira, M. A.; \& Pereira, P. R. G. (2010). Crescimento e absorção de nutrientes pela planta cebola cultivada no verão por semeadura direta e por transplantio de mudas. Bioscience Journal, 26, 59-70.

White, P. J., \& Broadley, M. R. (2005). Biofortifying crops with essential mineral elements. Trends in plant science, 10, 586-593. doi: 10.1016/j.tplants.2005.10.001

Winters, A. L., Lloyd, J. D., Jones, R., \& Merry, R. J. 2002. Evaluation of a rapid method for estimating free amino acids in silages. Animal feed science and technology, 99, 1-4. doi: 10.1016/S0377-8401(02)00112-8

Zhang, C., Zhang, H., \& Zhan, Z. (2016). Transcriptome Analysis of Sucrose Metabolism during Bulb Swelling and Development in Onion (Allium cepa L.). Frontiers in Plant Science, 7: 1425. doi:10.3389/fpls.2016.01425 